Danuta Życzyńska-Ciołek (1)

Polish Academy of Sciences, Poland

\title{
The Experience of Systemic Transformation in Contemporary Biographical Narratives of Older Poles ${ }^{1}$
}

DOI: http://dx.doi.org/10.18778/1733-8077.15.4.02

Abstract The aim of this article is to explore whether-from the subjective perspective of people born before the end of WWII-systemic transformation brought about significant changes in their individual lives, and if yes-what was the meaning of those changes for them. In particular, I examine how experiences related to the events that preceded systemic transformation in Poland or took place during its most intensive stage are reflected in contemporary biographical narratives of 49 persons aged 72 or more, for whom the period of professional activity, in whole or in major part, occurred in the times of the Polish People's Republic. I perform the analysis in three steps. First, I investigate the place of systemic transformation in the narratives, and consider the reasons why it is relatively often absent or poorly reflected there. Second, I present thematic motifs prevailing in those interviews where references to the systemic change appear. In the third step, I investigate the meaning of experiences connected with transformation for the narrators, the accompanying emotions-some of them still persisting-and ways in which the narrators incorporated those experiences into their biographies. The underlying narratives come from people who were drawn for a nationwide quantitative panel survey many years ago, in 1987, and participated in it for the next 25-30 years.

Keywords Systemic Transformation; Biographical Narrative; Older People; Polish Panel Survey POLPAN

Danuta Życzyńska-Ciołek is a Research and Archiving Specialist at the Institute of Philosophy and Sociology of the Polish Academy of Sciences. She has been a member of the Polish Panel Survey (POLPAN) research team since 2012. Her research interests include methodology of social sciences, social data archiving, biographical perspective in sociology, and life course studies.

email address: dzyczynska-ciolek@ifispan.waw.pl perceived them as a time when new opportunities and chances opened up, while others experienced a sense of uncertainty or social degradation; for many, the transformation brought about a mosaic of ambivalent experiences. The perception of, and adaptation to, these changes depended on many factors, well researched by macro-structural sociology, such as the place in the social structure (including different characteristics: from social origin, through education, to achieved status or position in the labor market), political views (often related to previous biographical experiences, one's own or parents'), and psychological characteristics (authoritarianism, self-confidence, etc.). ${ }^{2}$ In this context, a factor that undeniably influenced the type of experience associated with the most turbulent period of transformation was the age of the people who experienced the events. As Glen H. Elder Jr. (1994:6) wrote,

Especially in rapidly changing societies, differences in birth year expose individuals to different historical worlds, with their constraints and options. Individual life courses may well reflect these different times.

Systemic transformation created different opportunities and limitations for young people, who were

${ }_{2}^{2}$ Polish sociological literature on systemic transformation, both in the quantitative and qualitative paradigm, is extremely rich. and articles devoted to this topic: Kolasa-Nowak (2005; 2010; 2012; 2014), Doktór (2010). An edited volume containing a selection of sociological works from the 1990s (Krzemiński 2010) is also worth mentioning. As for the qualitative approach, I refer to selected works in footnote 17. Since empirical analysis presented in this article is based on (qualitative) data collected from the participants in the Polish Panel Survey POLPAN, (quantitative) part of POLPAN that are most relevant to the topic of systemic change in Poland: Slomczynski (2000; 2002), Slomczynski and Marquart-Pyatt (2007); see also articles listed on polpan.org/en/publications/articles. just entering adult life, ${ }^{3}$ as compared to conditions for mature people, for whom the period of the most intense professional activity and important personal decisions coincided with the times of the Polish People's Republic. In the period of social and economic changes, younger and older people were at different stages of their personal life and professional career; they differed in their life experiences and motivations, which often had an impact on how they perceived and experienced the changes. Moreover, contemporary survey studies (e.g., CBOS 2019a) indicate that even today -30 years after the most intensive transformational changes-age is one of the most important factors differentiating the opinions of respondents as to whether it was worthwhile to change the system in 1989 and whether the introduced changes brought more losses or benefits. Survey methods, however, cannot provide an exhaustive answer when we are interested in sources of such opinions, especially in their biographical background. This kind of analysis can be conducted with the use of qualitative methods.

Over the last few years, Polish sociologists who study social changes from a biographical perspective have devoted many publications to the subject of systemic transformation (e.g., Domecka and Mrozowicki 2008; Mrozowicki 2011; Gospodarczyk and Leyk 2012; Kaźmierska 2016). Most of these works focus on investigating the life courses of people born during the socialist era. In contrast, in this article, I analyze contemporary biographical narratives (collected in the last five years) of people born in the years 1922-1942 who were aged 72 or over at the Center, Poland: "Significant Life Events and Turning Points in the Biographies of the Oldest Respondents of the Polish Panel Survey POLPAN" (grant no. 2017/25/N/HS6/01928) and Multidimensional Biographies and Social Structure: Poland 1988-2018" (grant no. 2017/25/B/HS6/02697).
${ }^{3}$ See, e.g., Mach (2003; 2005), Tarkowska and Korzeniewska (2002), Tarkowska (2007), Rek-Woźniak (2016). 
time of the interview. In the symbolic breakthrough year of 1989, they were between 47 and 67 years old and were generally at an advanced stage of their careers or had already retired. What is also important, a vast majority of the narrators can be classified as so-called "ordinary people"-they were not active actors in social and political life during the transformation period.

Systemic transformation is widely regarded by historians and social researchers as the most important socio-political event (or rather process) in the postwar history of Poland. Its evaluation is still a subject of public debate; it is also connected with the assessment of the previous period, that of socialist regime. The aim of this article is to explore whether from the subjective perspective of people born before the end of the WWII systemic transformation brought about significant changes in their individual lives, and if yes-what was the meaning of those changes for them. In particular, I seek to answer the following research question: whether and how biographical stories of 49 narrators born in the years 1922-1942 reflect the experience of the most intensive period of systemic transformation, that is, the events of the 1980s and 1990s-the emergence and development of the "Solidarity" movement, the introduction of martial law, the economic crisis of the 1980s, the revival of "Solidarity" in the late 1980s, the collapse of the socialist system and related political changes of 1989 and the early 1990s, the economic transformation of the 1990s and its social consequences. I perform the analysis in three steps. First, I investigate the place of systemic transformation in the narratives, and consider the reasons why it is relatively often absent or poorly reflected there. Sec- ond, I present thematic motifs prevailing in those interviews where references to the systemic change appear. All three threads repeated in the largest number of interviews turn out to be related to the sphere of work and employment. In the third step, I seek to deepen the analysis by examining not only what the narrators are talking about, but also how they are doing it. I investigate the meaning of experiences connected with transformation for the narrators, the accompanying emotions-some of them still persisting-and ways in which the narrators incorporated those experiences into their biographies.

I consider my work to be a continuation and extension of the biographically orientated studies on Polish transformation that were carried out by the authors mentioned above. Due to presenting the experiences of older Poles, this article enhances the so far accumulated knowledge of the subjective perception of systemic change. The interviewees are over 72 and they perceive past events in a specific time perspective-the perspective of their long lives, which leads (at least some of) them to make summaries and undertake reflection on their entire biography. These facts allow us to see their experiences related to systemic transformation (or: the lack of such experiences) in a wide context of their life courses. Focusing on the narratives of the participants from one age group makes it possible to thoroughly analyze those aspects of their experiences from the period of systemic transformation that were related to their age and cohort(s) to which they belonged. The application of biographical approach leads to identifying some social and psychological mechanisms that are difficult to observe in survey studies, but are likely to contribute to the results obtained in them.

\section{Research Material and Method of Analysis}

This article is based on 49 biographical interviews conducted in 2014-2019 with selected respondents of the Polish Panel Survey POLPAN (www.polpan.org), born in the years 1922-1942, that is, belonging to the oldest group of the survey participants. POLPAN is a quantitative study of social structure, repeated every five years among the same respondents, with the participants from the youngest age group being regularly added in each wave since 1998. Originally, in 1987, respondents selected to participate in the POLPAN survey were aged 21-65 and formed a nationwide representative random sample (Słomczyński, Tomescu-Dubrow, and Dubrow 2015).

The authors of the biographical research project ${ }^{4}$ sought to select highly diverse interviewees in terms of education, belonging to socio-occupational categories (at the time of the interview or in the past), region, and size of the place of residence. As for occupational diversity, the "biographical subsample" consists of relatively many people with the experience of working in industrial plants, public offices, and institutions, or on a farm, yet there is only one artist and very few people who ran their own business during any period of their lives. This "imbalance" reflects-at least to some extent-the real occupational divisions that existed in the Polish

${ }^{4}$ All biographical interviews were conducted at the Institute of Philosophy and Sociology of the Polish Academy of Sciences, in three stages. The original project of the pilot biographical
study was developed by Dr. Piotr Filipkowski in cooperation study was developed by Dr. Piotr Filipkowski in cooperation
with Dr. Katarzyna Andrejuk and carried out with the participation of Danuta Życzyńska-Ciołek. The latter then continued this undertaking under two separate projects. Most of the interviews are available in Polish from the IFiS PAN Qualitative Data Archive (www.adj.ifispan.pl). society during the times of the Polish People's Republic. The basic socio-demographic characteristics of the narrators are presented in the appendix at the end of this article.

The consequence of selecting narrators from among the participants drawn (formerly) for the POLPAN survey is that the "biographical subsample" consists of people who experienced systemic transformation in different ways, or even, in their own opinion, did not experience it at all. They were not usually active actors in social and political life during the transformation period. They did not belong to the elites (neither old nor new) that shaped the new reality at a supra-individual level. The reason why they were selected for biographical research was also not because they belonged to the category of "beneficiaries" or "victims" of the transformation (Pisz 2000), its "winners" or "losers" (Jarosz 2005). To a certain extent, their ways of experiencing transformation may therefore overlap with the experiences of other so-called "ordinary" Poles, although, of course, we cannot speak of any "qualitative representativeness" here.

Although participants of the biographical project formally belong to the category of "the oldest POLPAN respondents," they do not represent a homogeneous age group and they certainly do not represent a generation in the sociological sense. The birth dates of the oldest and youngest narrators are as many as 20 years apart, which means that their socialization, education, and entering adulthood took place under very different historical circumstances: in the case of the oldest respondents, these processes had begun before WWII and were brutally interrupted by 
it, while in the case of the youngest ones, those processes fell entirely within the first two decades of the Polish People's Republic. As a consequence, the participants of the biographical project differ significantly in their experiences during the most formative periods of their lives, that is, childhood and youth. ${ }^{5}$ Also, the time of transformational breakthrough, which was conventionally set (at least until recently ${ }^{6}$ ) in 1989, "found" the narrators on various life stages: the oldest ones had already reached the age of 65 and sometimes had at least a few years of retirement behind them, while the youngest did not reach the age of 50 and had to face the labor market turbulences. Their experience and the way they lived through systemic transformation could therefore be varied also because of that reason, which probably has not been fully captured in this paper.

As the aspect of age is important for the analysis presented in this article, it is worth mentioning that there is a significant age difference between the narrators and the interviewers. The researchers who conducted the biographical interviews were in their 30 s or 40 s at that time, so they were at least 30 years (and sometimes many more) younger than the interviewees. I will refer to this fact in the next section of this article.

${ }^{5}$ In her book on adolescence of young people from intellectual families born in 1926-1930, Hanna Świda-Ziemba (2003) wrote about how the age difference of even one year could have significantly influenced the processes of socialization and educaion.

${ }^{6}$ In the CBOS survey of January 2019, the respondents were asked: "Which event can be said to mark the end of the com-
munist system in Poland?" The highest percentage of those munist system in Poland?" The highest percentage of those
surveyed, 25\%, chose, "The first completely democratic elections to the Polish Parliament and Senate in 1991," while 22\% indicated the "Round Table Talks in the spring of 1989." Ten years earlier, the respective percentages were $9 \%$ and $40 \%$ (CBOS 2019b).
The intention of the biographical project's authors was to conduct the interviews using the method of Fritz Schütze's (1983; 2016) autobiographical narrative interview, which means that the first, fundamental phase of the interview should consist in the respondents' free-flowing narrative on their own lives. In practice, the conversation often took the form of an unstructured, in-depth interview, usually with longer narrative fragments (Filipkowski and Życzyńska-Ciołek 2019). Also, the research was not aimed (especially initially) at exploring any specific subject or sociological problem (in particular: the systemic transformation experience). The researchers did not have a predetermined list of topics to be addressed or questions to be asked, whether in the final phase of the interview (if the interview was conducted according to the planned pattern), or in the course of the interview (if this form was not retained). Nevertheless, as far as events such as significant historical and political changes are concerned, the researchers usually asked questions about WWII and the period of transformational changes (if the interviewee did not raise these topics him/herself).

For the purpose of this article, I did not conduct an in-depth analysis of interviews using the Fritz Schütze's method, although I sometimes invoke his terminology and assumptions. I treated the interviews in a cross-sectional way, looking for references to the events of the 1980s and 1990s. ${ }^{7}$ In each case, however, before quoting or interpreting an interviewee's statement, I considered it in the context of the entire narrated biography. I focused on those fragments of the interviews that were narrative in

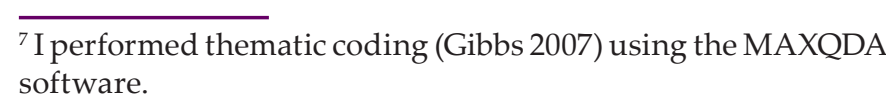

nature, that is, when the interviewees talked about events they took part in or events which took place in their immediate vicinity. These parts of the narratives were often accompanied by vivid emotions. I treated fragments which contained general opinions or comparisons (especially comparisons of the period "after the transformation"-or the narrative "present"-with the times of the Polish People's Republic) in a secondary way and I have not analyzed them in detail here. I assume that the analysis of narrative fragments allows us to get better insights into the interviewees' experiences at the time than the analysis of descriptive or argumentative parts. Although it seems appropriate to consider the "mediating aspect of time" (Piotrowski 2016a:239) and influences of public discourse(s) when collecting stories about events that took place 20 or 30 years ago, in this article, I decided to leave aside the issue of collective memory of systemic transformation, which has been already discussed by other authors (e.g., Bernhard and Kubik 2014; Breuer and Delius 2017; Laczó and Wawrzyniak 2017).

\section{(Non)Presence of Transformation in Biographical Narratives}

The first thing that draws attention when looking for "transformation themes" in the biographical interviews with the POLPAN respondents is the small number of spontaneous references to the historical circumstances and events of the 1980s and 1990s. This "omission" is not limited to purely political events (such as the Round Table Talks), which some of the narrators could then probably view as something that took place "somewhere far away, in Warsaw," in the sphere of politics that they were not interested in. It seemed more interesting to me that the interviewees relatively rarely spontaneously referred even to those social consequences of systemic transformation that were potentially felt in everyday life, such as, for example, the hyperinflation of 1989-1990 or unemployment rising in the 1990s. The narrators' stories about this period of their own biographies most often focused on situations from their family or occupational life, sometimes on health problems, and were devoid of a broader context, while the background for the events usually involved the closest social environment, co-created by the members of the narrator's family, friends, or co-workers. If we recall the distinction between two styles of narration developed in the 1990s by the Department of Sociology of Culture at the University of Lodz, one can say that the narratives discussed here were most often "inrooted in a milieu," while the cases of being "inrooted in history (theory)" were relatively rare (Piotrowski 2016a; 2016b). ${ }^{8}$ Adam Mrozowicki (2011:125) uses the expressions "neutralization of history" and "private frames of remembering" to characterize such a narrative style that omits the broader social and historical background. However, if references to the socio-political situation spontaneously appeared in interviews, they usually did when the "grand" history became directly present in the narrator's life, or the lives of

8 "Inrooting in history means...the narrator's tendency to place and interpret their own biographical and inter-biographical processes in the plan of historical and social macro processes and refer to theoretical categories (knowledge) and/or variou ideological and historiosophical models. From this perspec-
tive, the course of one's own experiences is presented as a case tive, the course of one's own experiences is presented as a case
that illustrates a general regularity. Inrooting in a milieu, on the other hand, involves telling and interpreting one's own experiences in terms of the course of events and dependencies taking place on a micro scale of the immediate living environment" (Piotrowski 2016b:49). 
their closest friends, which means that it was difficult for the narrator to explain their individual situation or the reasons behind their decisions without invoking history. It was often the case that the memories of these events were accompanied by emotions, still strong after 25 or 30 years. The kinds of situations and decisions that are meant here will be explained later on.

What happened when the researcher directly asked a question about the events of the 1980s and 1990s and their reflection in the narrator's life? Most often, the interlocutor recalled certain experiences and situations from their life or from the life of their immediate social circle that were connected with the transformational changes. Occasionally, these memories were placed in the context of collective identity, for example, the experiences of one's own socio-professional group. If the interviewee did not refer to the events from their own life when answering the researcher's question, they sometimes expressed general opinions and views on the changes that took place in the country (such reflections, not rooted in biographical experience, will be treated as a background in this article, since I am mostly interested in narratives about events). In a few interviews, however, the narrators clearly stated thatfrom their subjective perspective-they had not noticed systemic transformation at all, or had not been interested in it.

The absence or weak presence of historical circumstances in a biographical narrative may stem from various reasons. However, the issue of reasons suggests that this situation constitutes an exception that needs to be clarified. Perhaps the opposite is true: the focus on the spheres of family, ${ }^{9}$ work, and health is the norm, while the exceptions from this norm should be explained. However, in the discussion below, I will refer to the explanations I found in the empirical material.

Firstly, the narrators themselves sometimes explain their lack of interest in socio-political events by referring to their heavy burden of hard work that left neither time nor energy to look at their own lives from a broader perspective. Paradoxically, sometimes this justification coincides with a high value placed on such work. This factor would explain the absence of "grand" history in the narratives of the majority of farmers from our set of interviews, especially those who were poorly educated, sometimes struggling with difficult material situation, and sometimes simply attached to the idea of "hard work" as one of the central values of peasant tradition. One example can be a statement by Stefan, ${ }^{10}$ a farmer who was also a manual worker of the railways:

I wasn't particularly interested...I wasn't interested in that or... Because there was no time, you know, to follow it, because I had, well, I had 16 hectares of fields here! It was waiting for work to be done, and the animals... Four cows, two horses... You know, I had a lot of work to do. [W2/19]

However, a similar focus on tasks related to work can also be found in the biographical story of a private entrepreneur with secondary education, who managed his own business until the age of 75 (and later

${ }^{9}$ As CBOS surveys (2017; 2019c) show, most Poles invariably
point out that family is the most important value for them. ${ }^{10}$ The names of the interlocutors have been changed. worked part-time). When asked about the transformation, he immediately recalled an investment he was making at the time, and moved on to discuss its organizational and financial details, without any direct reference to the broader socio-political or economic situation. As this example suggests, it may not always be about the external necessity to focus on the sphere of work, but, instead, it is sometimes about a more or less conscious choice of priorities in life or about highly internationalized values.

Secondly, the focus on events from everyday or private life can be temporary, for example, caused by unexpected, sometimes dramatic events that coincided with the period of systemic transformation (as in the case of the female narrator who became a care provider of a disabled grandchild at that time, and experienced serious family problems). The interviews conducted within other studies (Mach 2018) and by myself in other projects ${ }^{11}$ indicate that the argument "I didn't have mental space for it at the time" is also used in relation to systemic transformation by younger people who started their adult lives during that period: they entered into relationships, started families, or were absorbed in their student life.

Thirdly, I believe that in the case of some interlocutors who fared quite well in the socialist system and held relatively high positions in it, the omission of the transformation as a topic may be due to their difficulties in surviving the collapse of the system and

For instance, the project "RePast-Revisiting the Past, Anticipating the Future," funded from the European Union's Horizon 2020 Research and Innovation Program (Grant
Agreement no. 769252). the concerns about today's evaluation of the narrators' previous role and attitudes.12 In Fritz Schütze's terminology, we would be dealing here with the fading out of awareness (Ausblendung): whether unintentional (in the past) or intentional (currently). ${ }^{13}$ Omission of difficult experiences may be connected with insufficient trust in the researcher, additionally reinforced by the current (as well as previous, existing in the early 1990s) public discourse, which stigmatized anything connected with the Polish People's Republic. Another reason for distrust may also be that the researcher-a person who is several decades younger-will not understand the complexity of the circumstances under which the narrator made his/her life decisions.

The fourth explanation would be related to the relativization of the importance of transformational changes: in the context of the narrators' other difficult experiences during their long lives, such changes may seem to be a relatively insignificant ${ }_{12}$ I suppose it might have been equally difficult for some peo-
ple to talk about participation in ownership transformations pre to talk about participation in ownership transformation
(privatization) in the 1990s, but I did not find such references in the interviews.

${ }^{13}$ One example is the biographical story of Maria, a civil servant who worked for 35 years in one of the central government agencies. She retired in late 1989 under circumstances tha were not fully explained in the interview. As she says, a new person was employed in the office at that time and she "reported to others." The narrator presents the previous atmosphere and working conditions in the office with great sentiment, she
also defends good opinions about Jerzy Urban, who was the face of government propaganda in the 1980s. At the same time, she answers the question about systemic transformation as follows: "You know, I have that character, my husband says I don't give a damn about anything...I didn't feel any such changes really" (W1/10). The interview reader can be struck by the contradiction between good memories of the socialist times and the narrator's marginalization (even banalization) of the expery contrasts with that of another narrator, Elżbieta, who openly spoke about her membership in ORMO (volunteer citizens' pospoke about her membership in ORMO (volunteer citizens' po-
lice) and her role in blocking the establishment of "Solidarity" in the office where she worked in a management position. 
historical turmoil. WWII, which ruined the childhood and youth of some interviewees, sometimes seems to be much more important in the contemporary narratives (despite the considerable distance in time) than any subsequent historical circumstances. ${ }^{14}$ The longue durée perspective used by the older narrators to view their lives is evidenced by the fact that when asked about the general assessment of the socialist period in Poland, they sometimes use comparisons referring not to the years after systemic transformation or to the present day, but to the situation before WWII, and they do so in the context of their own biographical experiences. Traumas and turning points in personal life (e.g., death of a child, sudden death of a beloved spouse) also may push other experiences to the background.

Fifthly, it seems that people who were not associated with any institution or company during the transition period (e.g., those who were economically inactive at the time) usually experienced the effects of the transformation in a less intensive way in their own lives and, therefore, sometimes do not mention those events in their narratives, unless the consequences of systemic changes were manifested in the lives of their loved ones, for example, their spouse or children. However, as regards people who were employed at that time, it should also be noted that the effects of transformation, both those perceived as positive and those felt as negative, were experienced differently in different working environments. Obviously, the type of position occupied at work could

14 Kaźmierska and Schütze (2013:125) also mention the memory of World War II, "still alive and dominant in the discourse of
biographical and collective memory." also have had an impact on the narrator's life trajectory in the transition period.

Sixthly, the inability to comment on the situation in the late 1980s and early 1990s may stem from the belief that the question about abstract "transformations" or "changes" is more about the world of "serious politics," which the interlocutor is not interested in ${ }^{15}$ has no influence on, or does not feel competent to comment on, and not about the experience of everyday life. The latter interpretation would be supported by a statement by Jacek, a foreman in a construction company, whose free-flowing narrative presented the reasons for his dismissal in the early 1990s as a coincidence of two circumstances: the manager's unfavorable attitude and the then poor economic situation in the country. However, when asked directly about the "transformation of 1989" and the accompanying feelings, Jacek answered:

[T] hat was a time when that unwanted man [not accepted by me] was my manager. And I was really so busy with my problems that I didn't care about the rest... [I] didn't care much...I was busy with myself...That's why I won't tell you anything about this topic. [W1/2]

${ }^{15}$ The POLPAN survey regularly asks a question about the respondents' degree of interest in politics. In 2018, a total of 17.2\% of all respondents declared that they were interested in politic to a large or very large extent, $38.3 \%$ to a moderate extent, and
$44.4 \%-$ to a small extent or not at all (weighted data). Amon POLPAN participants aged 72 and over, the percentage of rePOLPAN participants aged 72 and over, the percentage of re-
spondents interested in politics was slightly higher, but they were still the minority-the corresponding levels of interes were $23.6 \%, 38.9 \%$, and $37.2 \%$ respectively. In addition, in 2003 the respondents were asked the following open-ended question: "Throughout your entire life, what was the most important political event for you, the one you felt or experienced th
most?" Despite the question wording, suggesting a reference to most?" Despite the question wording, suggesting a reference to personal experience, as many as 34\% of respondents did not an-
swer that question (Wysmulek and Wysmulek 2016). These data prove that many Poles feel a sense of alienation from the world of politics.
At this point in the conversation, the narrator treated his career problems (which were clearly the consequence of systemic transformation) as an experience that was separated from the political and economic decisions taken at the country level at that time.

To sum up this part of the discussion: most of the discussed biographical narratives revolve around important events in personal lives or careers of the narrators or their loved ones. During the narrators' long lives, family ties often proved to be more stable and guaranteed a greater sense of security than the changing social and political circumstances. In this sense, interviewees place the "grand historical events" at the margin of their lives. On the other hand, the interlocutors had either limited influence or no influence on the historical circumstances (WWII, post-war poverty, Stalinist years, economic crises, etc.) accompanying successive stages of their lives, but they had to deal with the consequences. In the vast majority of cases, their individual agencies manifested themselves in reactions to the "wind of history" rather than an active influence on the mainstream course of events. In this sense, the narrators' lives happened on the margins of "grand history." The political, social, and economic changes of the 1980s and 1990s do not generally seem worth incorporating among the central events from one's own biography, unless they had a direct, non-negligible impact on individual life courses.

\section{What Do the Narrators Talk About?}

Dominant Topics, Situations, and Events

In this part of the article, I will present three selected thematic threads concerning the period of systemic transformation, which were raised by the narrators when talking about their experiences (about the events from their own lives). One common feature is that these threads were repeated in a relatively large number of interviews. They all concern the sphere of work and employment.

\section{The Need to Make Career Decisions in Conditions of Great Uncertainty}

The issues of the narrators' occupational situation in the context of the political events of the early 1980s, the economic crisis, personnel changes in institutions and companies, the labor market transformations in the 1990s, and the legal regulations changing with high frequency are present in almost twenty narratives. Many narrators were making important career decisions at that time, and did so in circumstances of considerable uncertainty. Some of them, seeing the deteriorating situation in their manufacturing plant or fearing that the reorganization of their institution would be detrimental for them, voluntarily applied for collective redundancies. Others, who had earned the relevant entitlements, opted for retirement or the so-called early retirement. The legal regulations at the time facilitated such decisions; there was a system of welfare benefits to help people who were only a few years from reaching retirement age (Cichon, Hagemejer, and Ruck 1997). The narrators often present their decisions as a combined result of the situation at work and other factors, for example, care duties in the family (spouse's illness, the need to help in looking after grandchildren, etc.). A recurring topic in the interviews is that of changing legal regulations and uncertainty as to whether the moment of making a decision is good: in some cases, a difference of a few 
days or weeks had measurable consequences, for example, it affected the amount of pension granted. In several cases, the narrators who voluntarily left their workplace to receive some kind of welfare benefit worked at the same place later, even for several years, usually on a part-time basis. Sometimes the managers of enterprises and institutions tried to circumvent the law to benefit the employees, as was the case with the factory where Maciej was employed:

Well, there was a transition period before retirement. Because then the laws made it easier, no special effort was needed. The enterprise was officially declaring that it was eliminating this position, even though it wasn't true. Often, you would continue to work for five years in the same position. But, your certificate of employment stated that you worked on another position or something. [W1/21]

Some narrators took up new jobs after retirement. However, they do not talk about this as a turning point which marked a new and important stage in their occupational path, but, rather, they view it as an "add-on" to their previous career, driven by the need to earn more money. Sometimes they were exposed to new organizational culture and work relations (often seen as inferior by the interviewees). This was the case with Tomasz:

You know, in these private companies, the atmosphere was completely different. No one trusted anyone, no friendly relations. [W1/19]

However, interviews also include stories of dismissal or forced retirement, not accepted by the employee. One of the most dramatic stories is that of Jacek, who suffered a stroke after receiving a termination notice (during a period of intense unemployment in his region of residence). Paradoxically, however, he considers this to be a positive fact, since he received a disability pension as a result, which enabled him to survive until his retirement. Another narrator had been working in a low-status job for several years before his retirement. Although the narrators sometimes complained about the low amount of pension granted during the transition period ${ }^{16}$ none of them mentioned having a personal experience of long-term unemployment or total lack of means of subsistence. ${ }^{17}$

\section{Personnel Changes, Interpersonal Tensions at the Workplace, "Helping Hands"}

The changes experienced by the narrators in the 1980s and 1990s often had the "faces" of specific people who were involved. The themes concerning interpersonal relations are very diverse. Some memories concern antagonisms that appeared between the members of the Communist Party (Polish United Workers' Party, PZPR) or official trade unions and supporters of the "Solidarity" trade union (NSZZ Solidarność). In several interviews, one can notice criticism of specif-

16 "The amount of benefits was kept low. This was due to a sharp increase in the number of pension recipients receiving
a pension between 1989 and 1991 . Many people were already
sent to retire early before 1989 in order to reduce the extent of sent to retire early before 1989 in order to reduce the extent of latent unemployment. In view of such a large number of ben-
eficiaries, it became impossible to maintain the level of peneficiaries, it became impossible to maintain the level of pen-
sions" (Ziomek 1999:63-64).

${ }^{17}$ Sometimes the narrators mentioned such experiences in relation to their children. Socio-economic consequences (especially those negative) of changes introduced in the 1990
have been widely described in the Polish sociological literature; see, e.g., Beskid (1992), Karwacki (2002), Palska (2002) Tarkowska (2000), Tarkowska and Sikorska (1995), Tarkowska, Warzywoda-Kruszyńska, and Wódz (2003), WarzywodaKruszyńska (1998). ic people from the narrators' immediate social circle who joined the "Solidarity" movement, sometimes performing important functions there ${ }^{18}$; following the changes of 1989-1990, some of those people took up managerial positions in the narrators' institutions or enterprises. The narrators accuse these people of hypocrisy and double standards: in their view, some of them had previously actively supported the Communist Party, but when the political sentiments changed, they began to declare pro-Solidarity views with zeal. Such people were also sometimes accused by the narrators of denunciation, lack of solidarity with other employees, attempts to make an easy career, making financial gains from being a trade union activist, incompetence, or even immoral or illegal behavior in private life. All the narrators who expressed such opinions had been members of the Communist Party in the past, although-according to their own declarations-they were forced to join and were not actively involved in the party.

Sometimes new executives and managers faced mistrust not because of their specific political behavior or attitudes, but rather because of their young age:

Later on, when things changed, we went private [the enterprise became privatized], and the young people were promoted and became our bosses. Whoever spoke English, knew about computers, and was under thirty was promoted as a branch manager or a floor manager. Those people often lacked professional experience and, above all, life experience. [W1/21]

18 Although this is not always explicitly stated, all these situa-
tions seem to concern the so-called "second Solidarity" tions seem to concern the so-called "second Solidarity," that is, the revival of the trade union in the late 1980 s.
Tensions between employees may also have been caused by a sense of threat due to potential redundancies or unemployment:

Well, later on, when the changes began, things changed a bit. Things weren't so nice anymore, there weren't good relations at work, things were different... An employee talking with an employee, you had to be careful what you say and to whom. [W2/6]

The interviews also include memories of specific difficult situations connected with interpersonal relations during the period of change. Janusz, who came to Silesia to find work in the early 1960s and joined the Polish United Workers' Party to obtain housing ("it was more of a room"), recalls the pacification of the workers' strike in the Wujek coal mine shortly after the introduction of martial law in Poland (December 1981):

At the workplace, even though they were colleagues, they would spit at my feet because I was a party member. [W2/11]

Barbara, the headmistress of a rural primary school, reported a situation when one of the teachers hung a cross in the school. The narrator was summoned to the municipal council to explain the matter. The whole situation made her so upset that she decided to retire (it was in 1987). Another narrator, Aldona, believes that her dismissal was facilitated by an unfriendly colleague who presented a negative opinion about her to the new manager.

However, the research material also contains stories about the narrators receiving assistance from friendly 
people or simply competent officials, or about human bonds which brought about new experiences during the period of change. Elżbieta, a fairly high-ranking official in the town hall, recalls a phone call from a friend of hers employed by the Social Insurance Institution (ZUS), which helped her to retire at a favorable moment (as a result, her pension was higher ${ }^{19}$ ). This situation can obviously be viewed negatively as an example of a member of the former nomenclature using resources that were not available to others. However, the narratives also mentioned examples of support provided under more "democratic" rules, also by persons representing various institutions. Teresa, a cleaning lady, received valuable help from a legal advisor from the public employment services: following the advice, she wrote a letter to the Voivod (head of province) and obtained permission to extend her unemployed status for an additional year, which helped her to financially survive until retirement, taking advantage of unemployment benefits. Tomasz, a technician in a construction company, was offered a job in a private company after retirement: the company was headed by a woman who used to work in his former workplace and who "wanted to hire a trusted person" (W1/19) in her newly established company.

\section{Turbulent Times for Factory Employees}

The narrators who worked in manufacturing facilities often mention what happened to their enterprises during the period of systemic transformation. ${ }^{20} \mathrm{In}$

${ }^{19}$ At least for some time, because later, as the narrator mentions, the legislation that made this possible was considered
unfair and a financial adjustment was made to the benefit. unfair and a financial adjustment was made to the benefit. ${ }^{20}$ This is also done by people who did not work in such plants, more than ten interviews the narrators mentioned the liquidation of the manufacturing plant, the gradual limitation of output and workforce, or the privatization of the enterprise, sometimes involving a division into several or even several dozen companies, the plant's assets being stolen or purchased by foreign capital. I will not provide here any quotes from the interviews because this type of narrative is widely known, and I will elaborate on this subject in the following section. The prevailing attitude towards those changes in the interviews is, of course, negative. Comments on positive outcomes of such transformation are very rare.

Of course, the three issues highlighted above do not exhaust all of the themes contained in the interviews. I decided to discuss only these three because, as mentioned earlier, they recurred in a relatively large number of interviews, and they also provide a good introduction to the last part of this article, devoted to the meaning of the events of the 1980s and 1990s for the narrators and different ways of dealing with them emotionally.

\section{The Biographical Meaning of the Systemic Transformation Experiences}

How did the narrators see the significance of their experiences during systemic transformation? How did those POLPAN respondents who mentioned the transformation-related events from their own lives incorporate these experiences into their biographies? How did these experiences affect their sense of identity, the sense of life, or their own self-image presented in a biographical story? What kinds of emotions are present in those memories? I attempt to answer these questions in this part of the article. Below I present selected "combinations" of the ways in which the narrators experienced systemic changes and how they incorporated them into their own biographies.

As I wrote earlier, many interviews lacked (extensive) references to events from the period of systemic transformation. Therefore, I decided to present here only three-in my opinion most distinctive-patterns that emerged from the research material, illustrated with quotes from selected interviews. When making a choice, I was guided by the following criteria: (a) in the chosen interviews, the material concerning the experiences of the systemic transformation period was relatively rich, (b) the narrators spoke about the events in which they personally participated, (c) judging from the content and structure of the interviews, these events were important for understanding the biographical path of the interviewees.

\section{Life "Put into Question"-Two Versions}

"Indeed, communism was repressive, but for many people, it was the home they had learned to live in." This statement, attributed to Jacek Kuroń by Zbigniew Mikołejko (2019:30), is a good reflection of the experiences reported by some narrators. In particular, the communist system became a "home" for some people from peasant or working class backgrounds, who took advantage of the educational opportunities and social advancement, usually associated with membership in the Communist Party (PZPR), where such membership was treated more or less instrumentally. ${ }^{21}$ Even if they noticed the re-

${ }^{21}$ An interesting article on upward social mobility of women in the Polish People's Republic was written on the basis of pressive aspects of the system, their own biographical experience was sometimes so positive that they played down any contradictory information. One of the strategies to reduce the sense of participation in a system that was morally dubious could be to focus on working conscientiously and minimizing political involvement. That was the choice of Aldona, who had been employed as a city clerk for many years. For people like her, the change of political and economic system represented a threat. Indeed, the narrator was forced to retire early:

[I] retired after I turned fifty-five. I mean, I didn't want to, but it was the whole, so to speak, transformation of these systems, and we were just... People like me, who performed some functions, especially in the home affairs department. People always said it was a political department. That's where various things were arranged. Well, all of the people who worked there were chased away. So I retired at the age of fifty-five in 1990...I was very bitter because... I wouldn't want to show you all this, but I was a highly valued employee, I received awards. I was awarded the Knight's Cross, a Gold Cross of Merit, a Silver Cross. I collected the Gold and Silver Cross of Merit in Warsaw. I was extremely bitter, and my mother's illness overwhelmed me so much that I decided not to do anything. Leave it the way it is. However, I still regret it because I did not deserve to be thrown out of the picture just like this; I had done thorough, honest work. [W1/6]

As we can infer from the last sentence (and from other fragments of the interview, not quoted here), the narrator has not managed to deal emotionally

selected interviews from the discussed collection (Andrejuk 2016) 
with the forced retirement to this day. For her, systemic transformation brought about a breakdown of biographical order, or-using Schütze's terminology-a beginning of trajectory.

Also Feliks, a long-term director of a technical college and a member of the Polish United Workers' Party (PZPR), found himself in a situation where, in the second half of the 1980s, his entire career, and perhaps also his life, was put under symbolic assessment. As he recalls, he passed the "exam" at that time:

[Y]ou needed to renew your appointment once every five years. Towards the end of my service time I faced a dilemma. I wasn't sure if they would appoint me for another term of office or not. But, strangely enough, the "Solidarity" trade union at the school wrote a long essay saying that, "he is the only guy." The teachers approved it, saying: [the narrator's name] will be the headmaster. [W3/4]

Together with the oldest school headmasters, Feliks was appointed to this position for an indefinite term. However, it soon became apparent that the new education authorities, related to "Solidarity," intended to cancel the previous arrangements and introduce a periodic assessment of all school headmasters. At that moment (it was 1991), the narrator decided to retire. Since then, he has used his spare time to collect materials on the history of the school where he used to work and to write down his memories. Some of those materials have been published as a book. During the interview, Feliks was most happy to talk about his school and his past career. One could get the impression that he is mentally liv- ing in the past. He mentions meetings with former students in the interview:

[T]here are such sentences that I hear. One of my former students would say: "Hey, you old commie." But, many others say: "You are, or were, the foundation of respect, and you promoted respect for the school." And that's a beautiful end of my service as a teacher. [W3/4]

There is no room for in-depth analysis of both interviews, so I will try to provide a brief summary: both narrators deeply experienced changes brought about by systemic transformation. In their case, these changes were associated with the end of their professional careers. Moreover, for Aldona and Feliks, the arrival of the new system meant calling into question the life path they had chosen, and undermining its value. The transformation-related changes resulted not only in a change of the narrators' status on the labor market, but were also perceived as an "attack" on the identity they had developed over the years, with essential components such as solid, reliable work done with commitment and dedication ("service," as described by Feliks), as well as decency and making sure not to harm anyone. The narrators still defend this identity, also in front of the the researcher who conducted the interviews.

However, there is another, more common form of "feeling at home" in the previous system. It was experienced not only by people who occupied managerial positions during socialist times, but also by those who worked in bottom-level positions and were not PZPR members. This feeling is connected with the stability of employment and, indirectly, sta- bility of life guaranteed by the communist system. One striking element in the collected narratives was the long period of work in a single company or institution mentioned by the interviewees: this period often stretched over 30 or even 40 years. The prevailing pattern of an occupational career trajectory in the interviews is that of an "anchor" (Domecka and Mrozowicki 2008). Quite naturally, such a long period of employment was conducive to various relations with the workplace and the co-workers that were established and then developed over the years. The feeling of attachment (to the workplace and to the workmates) was strengthened by the emphasis on collectivism and the priority given to the "common good" in the official propaganda, as well as by the pride related to being part of the modernization of the country in those years. In this context, the "annihilation of communist order" (Golczyńska-Grondas and Potoczna 2016:25), resulting in redundancies in many enterprises and institutions or a collapse of those entities, and the destabilization of the labor market, generated a sense of regret, humiliation, rejection, and "cancellation" of important areas of people's biographies. Perhaps this also stretched onto the sense of identity which consisted of such basis components as the belief in having made a personal contribution to the success of the organization and a sense of solidarity with colleagues.

The experiences of this kind can be illustrated with the case of Lucyna. She had worked her entire career as a skilled worker in large and prosperous plants manufacturing aircraft, helicopters, and their parts, for domestic and foreign markets. The narrator was strongly attached to her workplace. In the interview, she recalled that before her early retirement the company had no other orders and, as a result, produced potato graters, among other things. Although Lucyna is very brief here, the context of her entire narrative indicates that the "potato grater" becomes a symbol of humiliation and a loss of the sense of dignity enjoyed by the workers of what used to be a flagship plant in the Polish People's Republic.

In turn, Zbigniew, who was employed for many years as a carpenter producing furniture and other wooden products, talks about the construction of a new hall, which the employees volunteered to build without remuneration, and about the later history of the cooperative:

And the new plant was also in the name of the town]...but it was a bit out of town. I had bad feelings about it. I had already left [the cooperative], but my colleagues would go there to work. The plant was nicely built in the 1980s. It went on until the 1990s, they sold the plant to some private guy for little money. And selling was not that much of an issue, but that guy fired half of the people. He sacked them. Only a half of them stayed on, and then, whenever I met colleagues, everyone complained. They said, "We had put so much effort into it..." Well, we volunteered to build that plant, for free. We just had our regular wages, and we, and we worked after hours to build that plant. We would gather in groups... Well, we did various things to build it as soon as possible, to... [Before] [i]t was like this: there was a plant here, downstairs, there were halls, and people were living upstairs. Yeah, in the town, in the old buildings. And it was a bit dangerous already and, secondly, it was horribly crammed. When we built the elegant halls, that was 
quite a different story. But, we didn't enjoy it for too long. Things turned out differently. [W2/8]

Anselm L. Strauss (1959:93) called the turning points to be "critical incidents that occur to force the person to recognize that 'I am not the same as I was, as I used to be."' The situation is different in the case of narrators experiencing the feeling that the value of their entire life was being undermined: with the systemic transformation, their identity was called into question by the changed social environment. ${ }^{22}$ If they show nostalgia for the past, it can be not only an expression of the trauma they experienced, connected with the sudden and radical change (Sztompka 2000), or a tool for criticizing the present (Mikołajewska-Zając and Wawrzyniak 2016), but above all an attempt to defend their own identity and preserve their self-image. As Krystyna Kersten (2006:152-153; cf. also Synak 2000) wrote, a positive attitude towards the period of the Polish People's Republic could stem from defending the sense of one's own life:

To put it simply, those who believed in the communist utopia, those who-after adapting to the unwanted, but real situation-were rebuilding Warsaw with great commitment, building Nowa Huta, according to their understanding multiplying the nation's wealth, lifting Poland from centuries-long civilization backwardness, serving the society as doctors, teachers, developing Polish culture and science, and finally those who owed their social,

${ }^{22}$ In the article, I refer mainly to specific events that contributed to the emergence of this feeling among the narrators, but the anti-communist public discourse is a separate issue:
narrators argue against this discourse in the interviews. material, and cultural advancement to the "people's rule," are less inclined to criticize the Polish People's Republic because this would entail depreciating their attitudes and contradict the image stored in their memory.

\section{Disappointment and Unfulfilled Hopes}

Some of the narrators were more or less active in supporting the changes in the 1980s, but felt disappointed later. "Later" could mean very different periods: sometimes the disappointment occurred even before the first partially free elections in 1989, sometimes it coexisted with intense unemployment and liquidation of plants in the 1990s, sometimes emerged under the rule of the Civic Platform in 2007-2015, and sometimes appeared only recently, after the Law and Justice party started to implement its program called "Good Change" (since 2015). However, I will focus on the disappointments of the first period of systemic transformation. An example of a person with such experience is Antoni, who had worked as a driver in a poultry plant for 37 years. In the first minutes of the interview, he quotes an episode from his life, probably from the 1980s. Antoni was told to take the office workers from the plant including the new director, "assigned" by the party, to a propaganda meeting held in a nearby city. Unexpectedly, the director invited Antoni to join the assembly (according to the narrator, the aim was to boost the number of attendees). During the meeting, the director told the participants about the need to "tighten the belt": they should not expect salary increases in the nearest future, but rather, unfortunately, price rises in the shops. Antoni describes the follow-up events as follows:
He finished the discussion, that's all. I got up. And I started preaching to him! I addressed him as "citizen," as I had been taught. I couldn't say "comrade" because I wasn't a party member myself. There were no "Misters" at that time [I could not use this word], there were only "citizens." So I said, "Citizen Director, you know, I was taught that under socialism we would achieve prosperity, and what kind of prosperity is here? You are giving us one kilogram of meat per month! Food coupons? Is this prosperity?! These are actually survival rations." Everyone applauded me! [He claps]. And one woman...she rushed towards me, kissed me on the cheek. I swear! They applauded me! The guys say, "Fuck, he's gonna fire you now." "No, he won't, I told him the truth!" Everyone knew it, but nobody would say it because everyone was afraid... [I] continued: "When I was a child, my sisters would take me to the forest, to pick blueberries, cowberries, we would gather them. When the forest was getting bigger and darker, and there were no blueberries, we'd go back because there was a wrong track. Same thing here: we went astray, stepped off the path to socialism. Socialism was supposed to lead to prosperity. But, there was no such thing as prosperity here." That's what happened, ma'am. [W2/2]

From the very beginning of the interview, Antoni presents himself as a person who was critical of the then political system and who, perhaps under the influence of an impulse, gained a great deal of civil courage and acted as a people's tribune, hurling "the king is naked" directly in the face of the man who represented the authorities: socialism was supposed to look different. The interview does not provide much more information about the narrator's anti-communism involvement. He emphasizes that despite repeated pressure, he never joined the PZPR party, but was a member of the "Solidarity" movement. He says that during the period of systemic transformation, party members working in the factory "turned tails." But, soon Antoni gets emotional about what happened later to the plant. He sharply criticizes Lech Wałęsa and believes that the leader of "Solidarity" cooperated with the communist regime. The respondent also blames Wałęsa for not holding the communists, especially the UB (Polish Secret Police) members, accountable. He accuses the new political elites, as well as those who have taken over plants located in one of the cities of the region within the privatization process, of getting overly rich:

Look, three guys grabbed that company and turned themselves into millionaires. And they don't respect the people. [W2/2]

Antoni's outrage expressed in this fragment of the interview can be seen as echoing the media coverage because it cannot be a result of his personal experience. However, the narrator also makes references to the latter. The company he worked for was involved in the production and sale of chicken eggs. The narrator is proud to point out that the output was exported to Germany, Italy, and even Saudi Arabia during socialist times:

And the plant, not really a plant [sense: relatively small], but, you know, they generated so much revenue! Revenue for the government, but also people from the village would breed chickens and sell eggs. The eggs were good because the breeding was wild. Later on, people set up these industrial farms, and the eggs weren't the same anymore. [W2/2] 
When the narrator was retiring, the plant was already in decline, and was subsequently liquidated. This makes Antoni bitter.

Similar feelings were expressed by Lucyna, the aforementioned technical controller at the aircraft plant. Yet her biography is more complicated. Lucyna was active both in organizations supported by the former regime (Polish Youth Association, Polish United Workers' Party, and Women's League) and in "Solidarity." There is no clear moment in her biography when she would change her views; it seems that contradictory ideological currents often simply coexisted in her life. The experience that could have tipped the balance (but it did not) was the involvement of her son, a student, in strikes at a university and the resulting need to hide from the authorities during the martial law. Lucyna says that during this period she not only faced the militia looking for her son, but also took part in demonstration walks during the time of night TV news shows (these walks were supposed to show the authorities that the citizens did not accept the propaganda sent via the media). When asked about her "Solidarity" membership, she says:

Of course, I always had to get involved. That's how it was. I always had the urge to get involved. When there was Solidarity, ma'am, I was on the social committee, but then I quit Solidarity because I didn't like it. I was on the [Solidarity] committee, and so on. From the very beginning, I tried to help them organize themselves in the plant, help the people, because I always had some volunteering in the plant, some kind of social work. But, most of all, I was involved in the social sector-I organized children's camps, and kids would go there. All kinds of things. And there were all kinds of unions, different societies, they always asked me to join in, to keep an eye on things...to attend the party [PZPR] meetings...I was always involved in things. [W1/3]

Lucyna quit "Solidarity" for several reasons. She did not like the people who became members of the works council and she was discouraged by the disproportionately high salary of the union chairman. As she says, she thought it was suspicious that the "Solidarity" members did not have membership cards (perhaps she was upset about the lack of transparency as to who is and who is not a member of that trade union). Much like Antoni, Lucyna expressed her mistrust of Lech Wałęsa:

I began to dislike Wałęsa's rule. Everyone knows Wałęsa, but you know what, I even started to suspect that he's not with us fully, not all the way. Whenever something was to happen, Wałęsa would get arrested. Why?... [T]hey knew things earlier, he was always covered, not by us, not by people, not by Solidarity, but he was shielded by the [communist] party. I didn't like it. [W1/3]

Both of these narratives come from the respondents with a working class background. Both correspond with phenomena which were discussed by researchers and journalists who analyzed the weaknesses and failures of the transformation process: mistrust towards the elites among the workers, a sense of distance from the actions taken by the elites, opposition to growing social inequalities, a desire for egalitarianism, no acceptance for radical economic changes. As Domecka (2016:60) writes,

[A]ll these changes hit mostly those who made them possible. Solidarity, which started as a trade union and a broad social movement of people who wanted a better life, became a political power valuing other concerns over social justice.

In both cases, however, based on the broader context of the whole interview, I believe that the experienced disappointment did not cause a mental "latch" in the past for these two narrators. Their lives go on, now filled mainly with family matters and health issues, and the emotions associated with the transformation-related experiences return mainly when they watch TV news.

\section{Fulfilled Hopes. Life Gets “Confirmed”}

Among the interviews analyzed here, Maciej's story is the most clear example of a successful adaptation to transformation-related changes (something he supported right from the start), which resulted in a sense of satisfaction and fulfillment. The narrator, born in 1940, completed a technical secondary school and immediately took up a job at a plant that manufactured electrical equipment. He worked in various positions there: as the "workshop planner," fitter, foreman, until he retired in 2000. He never joined the Polish United Workers' Party. In the interview, he repeatedly referred to examples of communist mismanagement and low ethical standards, which he knows from his own work at the plant:

There were many different positions and even if a lazy guy and a drunkard started working on the floor, he was tolerated, up to a point. Then he moved to floor B, and the halls were numbered up to G. So it took years for him to end up at floor $\mathrm{G}$ at the plant... Looking back, years later, we can see that many of these jobs were superfluous. [W1/21]
And so it was. At first, under communism, when there was a delegation going somewhere, to a coal mine or a power plant, people would always sign to confirm that the delegation stayed three to four days longer. People would return home, but would get the money to buy accommodation and per diems. That's how people would earn [extra] money. Maybe we should be ashamed of it today, but it's like this... You know, everyone did that. The engineer who went with that worker, he did, and some other employee did, too. It was customary to do so. [W1/21]

The plan was a sacred thing. There were so-called production meetings and then things were discussed, starting with the foreman, everyone expressed their opinion. "The plan is feasible, comrades, we just have to do the following..." And then the head of production would come and there was a casual conversation: "Boss, we can't manage, we can't do it.” “Look, there's a plan, and there's an adjustment to the plan later." And then the generator, which was the apple of our eye, because it had a production cycle stretching over many months, was reported in December as ready, but it appeared on the conveyer belt, which is the final phase of the assembly, only in June of the following year. It was all fictitious. [W1/21]

Phrases such as "looking back, years later, we can see" and "we should be ashamed of it today" point to the critical reflection that Maciej has applied to his professional past as time passed and new experience accumulated; this indicates that he performed his biographical work (Schütze 2016) to reconcile and internally integrate his own experiences.

Maciej says that he was a member of two, if not three, Solidarity works committees. Asked by the researcher, he declares that he had no difficulties at 
work because of his involvement, but he earned the opinion of "the crazy guy":

Because they knew that when on the thirteenth day of every month ${ }^{23}$ people would go out for a break and gathered at the main road, then nobody tried to stop me anymore because they knew I'd go there anyway. [W1/21]

The narrator talks about the visits of "Solidarity" activists to the plant, he also says that one of them was even employed by the company as his subordinate for some time. When asked how he perceived the changes that occurred in 1989, Maciej states that he looked at them with hope, like everyone else, including party members. "We all wanted something different," he says. He adds, however: "Though later we said that was not what we had expected."

In 1990, the plant was sold to a foreign corporation and divided into companies; a few years later, further organizational and ownership transformations took place. Maciej claims that he personally did not feel threatened with redundancy during the privatization period (although he acknowledges that others may have felt this way and confirms the researcher's suggestion that the employment figure actually decreased) and that he did not experience any stress related to change. He mentions training courses where the new management taught employees to admit a mistake right away. This was contrary to the previous practice, when errors were hidden and the plant incurred huge costs due to the detec- tion of "imperfections" of the manufactured equipment only after some time, once it reached the user. The narrator views the changes positively:

Maciej: Certainly, higher culture and completely different products are being made now. They go out to the entire world and those are high quality products.

Researcher: And the atmosphere, the relations with people, was it better then, or perhaps it didn't change? Maciej: It did change, it changed radically. There is perhaps a different [=better] kind of respect for work and different care. [W1/21]

Maciej also appreciates how the issue of overtime has been resolved: in the past, employees used to depend on informal pressure from their superiors, but later the system was changed.

Summing up his career, which began under socialism and ended under capitalism, the narrator says:

This is a plant that makes large electrical machines, so [it produced things] starting from some kind of motors for traction, fans for railways, drives for generators, and generators. Today, I am somewhat proud of it because [power plant in] Bełchatów, all ten generators, three hundred and sixty megawatts, that's partly my work. Opole power plant, four generators, three hundred and sixty megawatts... One, because there are... Right now, I forgot the name of that neighborhood. There's a piece of my own work in there, too. And in Africa, and India, and China. And somewhere on the Soviet ships that were built at the time. Because the shipyard in Gdańsk, usually had... When you walked along the waterfront, there was Ivan $X$, Sergei $Y . .$. It was made for Russia because they apparently had convert- ed all their shipyards to work for the Navy. Civilian ships were built by Poland. There is certainly a grain of truth in there. The equipment, top class stuff, had to be bought in England, and so on. We didn't produce it. But, we made generators for ships... Because a navy ship is a naval unit. So we made generators for ships, and they are out in the waters somewhere, I don't even know [where]. Apart from Antarctica, where penguins walk around. I certainly won't find my contribution there. But, otherwise, I can find it everywhere. [W1/21]

Maciej says that when he retired, he said to the HR manager:

You know, I'm leaving with my head up high. I didn't have any argument, no drunkenness, no theft... So I'm leaving the plant in peace. [W1/21]

His "departure with his head up high" seems to be more than just a feeling that he did not break any basic moral principles in the course of his occupational life. This phrase probably also reflects the satisfaction with the systemic change that the narrator expected and viewed positively (though not uncritically). It also expresses satisfaction with being able to adapt to the new working conditions in a changed economic and social reality. Finally, despite verbalized criticism of the socialist era, there is also a feeling that the effort made throughout his whole career made sense, since the effects of his work can still be found in many places around the world. ${ }^{24}$ The experience gained in the course of his life confirmed the accuracy and sense of Maciej's life choices.

${ }^{24}$ Piotr Filipkowski (2018) finds very similar "sense-making" themes for work in shipbuilding in the narratives of Gdynia shipyard workers.
The above review of the narrated experience of the events of the 1980s and 1990s in Poland and the ways of coping with them is not exhaustive, obviously, even if we take into account only the material from the interviews that have been analyzed here. Other options are also possible, such as the feeling of peace and satisfaction with one's own choices despite them being called into question by the new reality. We can also find pragmatism that helps the narrators not to worry too much about various turns and effects of transformational processes, alongside a sense of being stuck in ambivalence with regard to the assessment of the past and the present, both collective and individual. Also, one can relatively often come across a firm view (positive or negative) on the outcomes of the transformation, despite having no significant personal experience related to the events of the 1980s and 1990s. As I wish to adhere to the criteria set out at the beginning of this section, I do not describe those alternative variants here.

\section{Conclusion: What Can We See through the Prism of Individual Experiences?}

The author of the report entitled "Was It Worth Changing the System?" writes: "The social consequences of the changes taking place in Poland since 1989 have been seen through the lens of individual experience" (CBOS 2019a:8). By this the author means that those who believe that they and their families benefited from the transformation tend to assess the systemic change positively. Conversely, the respondents who declare that the changes brought them more losses than gains tend to see the transformation as a failure. The analysis of biographical interviews 
allows us to go beyond the "loss-benefit" dichotomy and to see the complexity and diversity of individual experiences mentioned in the CBOS report, as well as different ways of incorporating them in biographies. On the one hand, it makes it possible to see how these experiences "work" today in some person's internal world and how deeply they are rooted. On the other hand, it suggests that many people may assess the systemic change, or at least its first period, on the basis of observations and external messages (coming

\section{References}

Andrejuk, Katarzyna. 2016. “Awans społeczny kobiet w czasach PRL. Dynamika struktury i sprawczości." Przeglad Socjologiczny 65(3):157-179.

Bernhard, Michael and Jan Kubik. 2014. "Roundtable Discord: The Contested Legacy of 1989 in Poland." Pp. 60-84 in Twenty Years After Communism, edited by M. Bernhard and J. Kubik. New York: Oxford University Press.

Beskid, Lidia (ed.). 1992. Warunki życia i kondycja Polaków na poczatku zmian systemowych. Warsaw: Wydawnictwo IFiS PAN.

Breuer, Lars and Anna Delius. 2017. "1989 in European Vernacular Memory." East European Politics and Societies 31(3):456-478.

CBOS (Public Opinion Research Center). 2017. Sens życia wczoraj $i$ dziś. Komunikat $z$ badań. Warsaw: Fundacja Centrum Badania Opinii Społecznej.

CBOS (Public Opinion Research Center). 2019a. Czy warto było zmieniać ustrój? Ocena przemian po 1989 roku. Komunikat z badań. Warsaw: Fundacja Centrum Badania Opinii Społecznej.

CBOS (Public Opinion Research Center). 2019b. Trzydziesta rocznica obrad Okragtego Stołu. Komunikat z badań. Warsaw: Fundacja Centrum Badania Opinii Społecznej. from the media or social networks) rather than based on their own experience. Last but not least, the narratives of older people give an insight into the specific experiences related to the stage of life at which they experienced a radical social change. What is the point of doing all this? The answer might be pragmatic and "academic": to have a better understanding of election results, for example. However, I prefer a different answer, even if it may seem somewhat pompous: in order to understand each other better.

CBOS (Public Opinion Research Center). 2019c. Rodzina - jej znaczenie i rozumienie. Komunikat z badań. Warsaw: Fundacja Centrum Badania Opinii Społecznej.

Cichon, Michael, Krzysztof Hagemejer, and Markus Ruck. 1997. “Social Protection and Pension Systems in Central and Eastern Europe." ILO-CEET Working Paper No. 21. Retrieved September 17, 2019 (https://www.ilo.org/public/libdoc/ilo/1997/97B09_305_engl.pdf).

Doktór, Kazimierz. 2010. “Transformacja w perspektywie socjologicznej." Forum Socjologiczne 1:15-29.

Domecka, Markieta. 2016. “Biographical Experiences of Post-Socialist Transformation in Corporate Business: Doing the Neoliberal Path." Przeglad Socjologii Jakościowej 12(2):56-77.

Domecka, Markieta and Adam Mrozowicki. 2008. “Robotnicy i ludzie biznesu: wzory karier zawodowych a zmiana społeczn w Polsce." Przeglad Socjologii Jakościowej 4(1):136-155.

Elder Jr, Glen H. 1994. “Time, Human Agency, and Social Change: Perspectives on the Life Course." Social Psychology Quarterly 57(1):-15.

Filipkowski, Piotr. 2018. "Stocznia - transformacja - historie mówione. Albo o sensotwórczej mocy (gdyńskich) statków." Rocznik Antropologii Historii: Kulturowa Historia Wiedzy 11. Retrieved September 17, 2019 (http://rah.pth.net.pl/pl/archiwum).
Filipkowski, Piotr and Danuta Życzyńska-Ciołek. 2019. “From a Case to a Case Study-And Back, or on the Search for Everyman in Biographical Research." Przeglad Socjologii Jakościowej 15(2):40-57.

Gibbs, Graham R. 2007. Analyzing Qualitative Data. The Sage Qualitative Research Kit. Thousand Oaks, CA: Sage Publications.

Golczyńska-Grondas, Agnieszka and Małgorzata Potoczna. 2016. "Z klasy robotniczej do pomocy społecznej. Biograficzne doświadczenia dawnych 'beneficjentów socjalizmu' w postindustrialnym polskim mieście." Przeglad Socjologii Jakościowej 12(2):18-34.

Gospodarczyk, Hanna and Aleksandra Leyk. 2012. "Prywatyzacja w perspektywie biograficznej. Człowiek zakorzeniony, człowiek plastyczny, człowiek stłamszony." Acta Universitatis Lodziensis, Folia Sociologica 41:237-256.

Jarosz, Maria (ed.). 2005. Wygrani i przegrani polskiej transformacji. Warsaw: Oficyna Naukowa: Instytut Studiów Politycznych PAN.

Karwacki, Arkadiusz. 2002. "The Culture of Poverty in the PostState Farm Community." Eastern European Countryside 8:79-93.

Kaźmierska, Kaja (ed.). 2016. “Proces transformacji w doświadczeniach biograficznych." Przeglad Sociologii Iakościowej 12(2):6-16.

Kaźmierska, Kaja and Fritz Schütze. 2013. “Wykorzystanie autobiograficznego wywiadu narracyjnego w badaniach nad konstruowaniem obrazu przeszłości w biografii: na przykładzie socjologicznego porównania narracji na temat życia w PRL i NRD." Przeglad Socjologii Jakóćciowej 9(4):122-139.

Kersten, Krystyna. 2006. “Dyskusja nad historią PRL.” Pp. 152161 in Krystyna Kersten. Pisma rozproszone, edited by T. Szarota and D. Libionka. Torun: Wydawnictwo Adam Marszałek.

Kolasa-Nowak, Agnieszka. 2005. “Polskie studia nad transformacją: kierunki konceptualizacji.” Nauka 4:117-132.

Kolasa-Nowak, Agnieszka. 2010. Zmiana systemowa w Polsce w interpretacjach socjologicznych. Lublin: Wydawnictwo Uniwersytetu Marii Curie-Skłodowskiej.

Kolasa-Nowak, Agnieszka. 2012. “Transformacja systemowa w interpretacjach polskich socjologów. Tworzenie wiedzy w warunkach zmiany społecznej." Principia. Pisma koncepcyjne z filozofii i socjologii teoretycznej 56:65-82.

Kolasa-Nowak, Agnieszka. 2014. “Polish Sociology after Twenty-Five Years of Post-Communist Transformation. An Assessment of Achievements and Overview of Prospects." Soziologie 43(4):399-425.

Krzemiński, Ireneusz (ed.). 2010. Wielka transformacja: zmiany ustroju w Polsce po 1989. Warsaw: Oficyna Wydawnicza Łośgraf.

Laczó, Ferenc and Joanna Wawrzyniak. 2017. “Memories of 1989 in Europe between Hope, Dismay, and Neglect." East European Politics and Societies 31(3):431-438.

Mach, Bogdan W. 2003. Pokolenie historycznej nadziei i codziennego ryzyka: spoteczne losy osiemnastolatków z roku 1989. Warsaw: Instytut Studiów Politycznych Polskiej Akademii Nauk.

Mach, Bogdan W. 2005. Transformacja systemu a trajektorie życiowe młodych pokolen. Warsaw: Wydawnictwo IFiS PAN.

Mach, Bogdan W. 2018. Zblizajac się do 40-tki: Spoteczno-ekonomiczne trajektorie i polityczne biografie osiemnastolatków z roku 1989: kolekcja wywiadów. Warsaw: Instytut Filozofii i Socjologi Polskiej Akademii Nauk.

Mikołajewska-Zając, Karolina and Joanna Wawrzyniak. 2016. "Nostalgia jako narzędzie krytyki transformacji. Mit dobrego właściciela w opowieściach pracowników fabrycznych." Przeglad Socjologii Jakościowej 12(2):36-54.

Mikołejko, Zbigniew. 2019. “Dzika wolność.” Newsweek. Wydanie specjalne: Wywiady 3:28-31.

Mrozowicki, Adam. 2011. Coping with Social Change: Life Strategies of Workers in Poland's New Capitalism. Leuven: Leuven University Press.

Palska, Hanna. 2002. Bieda i dostatek: o nowych stylach życia w Polsce końca lat dziewięćdziesiatych. Warsaw: Wydawnictwo IFiS PAN.

Piotrowski, Andrzej. 2016a. "Zakorzenienie w historii (teorii) - zakorzenienie w milieu: analiza dwu odmian narracji." Pp. 239-259 in Biografia i wojna. Metoda biograficzna w badaniu 
procesów spotecznych, edited by R. Dopierała and K. Waniek. Lodz: Wydawnictwo Uniwersytetu Łódzkiego.

Piotrowski, Andrzej. 2016b. “Wprowadzenie do projektu Biografia a tożsamość narodowa." Pp. 43-52 in Biografia i wojna. Metoda biograficzna w badaniu procesów spotecznych, edited by R. Dopierała and K. Waniek. Lodz: Wydawnictwo Uniwersytetu Łódzkiego.

Pisz, Zdzisław. 2000. “Doświadczenia społeczne w procesie transformacji systemowej w Polsce w latach dziewięćdziesiątych." Problemy Polityki Spotecznej. Studia i Dyskusje 2:101-119.

Rek-Woźniak, Magdalena. 2016. Młodzi dorośli. Wzory ruchliwości spotecznej w okresie transformacji systemowej. Lodz: Wydawnictwo Uniwersytetu Łódzkiego.

Schütze, Fritz. 1983. "Biographieforschung und narratives Interview." Neue Praxis 13(3):283-293.

Schütze, Fritz. 2016. "Biography Analysis on the Empirical Base of Autobiographical Narratives: How to Analyze Autobiographical Narrative Interviews." Pp. 75-116 in Sozialwissenschaftliche Prozessanalyse: Grundlagen Der Qualitativen Sozialforschung, edited by H. H. Krüger and W. Fiedler. Opladen, Berlin, Toronto: Verlag Barbara Budrich.

Slomczynski, Kazimierz M. ed. 2000. Social Patterns of Being Political: The Initial Phase of the Post-Communist Transition in Poland. Warsaw: IFiS Publishers.

Slomczynski, Kazimierz M. (ed.). 2002. Social Structure: Changes and Linkages: The Advanced Phase of the Post-Communist Transition in Poland. Warsaw: IFiS Publishers.

Slomczynski, Kazimierz M. and Sandra T. Marquart-Pyatt (eds.). 2007. Continuity and Change in Social Life: Structural and Psychological Adjustment in Poland. Warsaw: IFiS Publishers.

Słomczyński, Kazimierz M., Irina Tomescu-Dubrow, and Joshua Kjerulf Dubrow. 2015. “Changes in Social Structure, Class, and Stratification: The Polish Panel Survey (POLPAN)." ASK: Research \& Methods 24(1):19-37.

Strauss, Anselm L. 1959. Mirrors and Masks: The Search for Identity. Glencoe, IL: The Free Press.
Synak, Brunon. 2000. “Pozycja społeczna ludzi starszych w warunkach zmian ustrojowych i cywilizacyino-kulturowych." Pp. 7-15 in Ludzie starzy w warunkach transformacii ustrojowej, edited by B. Synak. Gdansk: Wydawnictwo Uniwersytetu Gdańskiego.

Sztompka, Piotr. 2000. Trauma wielkiej zmiany: Spoteczne koszty transformacii. Warsaw: Instytut Studiów Politycznych PAN.

Świda-Ziemba, Hanna. 2003. Urwany lot. Pokolenie inteligenckiej młodziė̇y powojennej w świetle listów i pamiętników z lat 19451948. Cracow: Wydawnictwo Literackie.

Tarkowska, Elżbieta (ed.). 2000. Zrozumieć biednego: o dawnej i obecnej biedzie w Polsce. Warsaw: „Typografika”.

Tarkowska, Elżbieta (ed.). 2007. Ubóstwo i wyklluczenie spoteczne mło dzieży: raport z badań. Warsaw: Instytut Pracy i Spraw Socjalnych.

Tarkowska, Elżbieta and Katarzyna Korzeniewska. 2002 Młodzież z bytych PGR-ów: raport $z$ badań. Warsaw: Instytut Spraw Publicznych.

Tarkowska, Elżbieta and Joanna Sikorska. 1995. “Social History of Poverty: Polish Experiences and Research Perspectives." In The Social History of Poverty in Central Europe, edited by J. Szalai. Budapest: Max Weber Foundation.

Tarkowska, Elżbieta, Wielisława Warzywoda-Kruszyńska, and Kazimiera Wódz (eds.). 2003. Biedni o sobie i swoim życiu. Katowice, Warsaw: Śląsk.

Warzywoda-Kruszyńska, Wielisława (ed.). 1998. Żyć i pracować w enklawach biedy (klimaty łódzkie). Lodz: Instytut Socjologii Uniwersytetu Łódzkiego.

Wysmułek, Ilona and Jakub Wysmułek. 2016. “Ślady historycznego doświadczenia w wyborach życiowych współczesnych Polaków." Pp. 212-232 in Przemiany kulturowe we wspótczesnej Polsce. Ramy, wataściwości, epizody, edited by J. Kurczewska with cooperation of M. Karkowska. Warsaw: Wydawnictwo IFiS PAN.

Ziomek, Agnieszka. 1999. "Skutki procesu polskiej transfor macji w grupie ludzi starszych (zarys problematyki)." Ruch Prawniczy, Ekonomiczny i Socjologiczny 61(1):57-65.

\section{Appendix: Socio-Demographic Characteristics of the Narrators.}

\begin{tabular}{|l|r|}
\hline Characteristic & Frequency \\
\hline Gender & 28 \\
\hline Female & 21 \\
\hline Male & \\
\hline Year of birth & 4 \\
\hline 1922-1926 & 17 \\
\hline 1927-1932 & 13 \\
\hline $1933-1937$ & 15 \\
\hline 1938-1942 & \\
\hline Place of residence-region of Poland (NTS 1) & 10 \\
\hline Central & 8 \\
\hline South & 13 \\
\hline East & 10 \\
\hline North-West & 5 \\
\hline South-West & 3 \\
\hline North & 18 \\
\hline Place of residence-size of locality & 6 \\
\hline Rural & 7 \\
\hline Towns below 20,000 & 6 \\
\hline Towns 20,000-99,999 & 12 \\
\hline Towns 100,000-499,999 & \\
\hline Towns over 500,000 & 16 \\
\hline Education* & 8 \\
\hline Elementary or below & 4 \\
\hline Basic vocational & 8 \\
\hline General secondary & 6 \\
\hline Vocational secondary & 7 \\
\hline Tertiary-1: BA or equivalent / Post-secondary & \\
\hline Tertiary-2: MA, MD, or equivalent & 2 \\
\hline Last job before retirement-socio-occupational category* & 4 \\
\hline High level officials and managers & 2 \\
\hline Professionals & 7 \\
\hline Technical specialists & 6 \\
\hline Technicians & 2 \\
\hline Administrative workers and middle-level specialists & 2 \\
\hline Office workers & 8 \\
\hline Sales and service workers & 3 \\
\hline Skilled manual workers & 2 \\
\hline Manual workers in elementary occupations & 8 \\
\hline Unskilled workers in services and trade & 1 \\
\hline Farm owners & 1 \\
\hline Business owners & 1 \\
\hline No job that would entitle the respondent to retirement benefits & \\
\hline No answer & \\
\hline * According to POLPAN 2013 survey data. & \\
\hline
\end{tabular}

Życzyńska-Ciołek, Danuta. 2019. “The Experience of Systemic Transformation in Contemporary Biographical Narratives of Older Poles." Qualitative Sociology Revieww 15(4):20-45. Retrieved Month, Year (http://www.qualitativesociologyreview.org/ENG/ archive_eng.php). DOI: http://dx.doi.org/10.18778/1733-8077.15.4.02 